\title{
An Open Label Three Arm Controlled on the Effect of Udvarttana and Abdominal Pack in Central Obesity
}

\author{
Research Article
}

\section{Aparna Anand ${ }^{*}$, Vandana Rani $\mathbf{M}^{2}$, Anusree Dileep ${ }^{3}$}

1. PG Scholar, 2. Professor, 3. Associate Professor

Department of Swasthavritta, Amrita School of Ayurveda, Kerala, India

\begin{abstract}
Background: Obesity occupies first place among non-communicable diseases creating an enormous socioeconomic and public health burden in most of the countries. Body fat distribution, especially visceral adipose tissue accumulation, has been found to be a major correlate of a cluster of diabetogenic and atherogenic abnormalities that comes under the metabolic syndrome. Sthoulya is the nearest clinical entity in Ayurveda comparable to obesity. The treatment modality recommended for sthoulya is Langhana, Atarpana, Rookshana. Udvarttana, a procedure which gives rookshana with kapha medo samana is usually applied in sthoulya. In Naturopathy, exposure of cold increases metabolic reaction and is effectively used in obesity. Aim: The present study was made to evaluate the combined effect of Udvarttana and Abdominal pack together to manage the central obesity. Study design: Open label three arm-controlled study. Materials and Methods: Patients were randomly divided into 3 groups $(\mathrm{N}=60)$ and clinical study was conducted. Group $1(\mathrm{~N}=20)$ patients were given Sthaanika Udvarttana with Triphala Churna. Duration- 20 min. Group $2(\mathrm{~N}=20)$ patients were given Udvarttana with Triphala Churna and Abdominal pack. Duration -20 min Udvarttana and 30 min for Abdominal pack. Group 3 $(\mathrm{N}=20)$ patients and all the patients were given diet restriction (14 days). The findings were recorded and, one-way analysis of variance (ANOVA) with POST HOC TUKEY HSD was used to find the Significance between the groups. Results: By analysing the data, there was significant change in all assessment criteria's (waist circumference, hip circumference, waist-hip ratio, abdominal skinfold measurement) of Group 2 while comparing with the means of other two groups i.e. Group 1 and Group 3. Conclusion: The combined treatment of Udvarttana with abdominal pack showed better results than Udvarttana alone or diet restrictions alone. Udvarttana along with Abdominal pack proves to be an effective remedial measure for central obesity.
\end{abstract}

Keywords: Abdominal wet pack, Central obesity, Sthoulya, Udvarttana.

\section{Introduction}

India is the world's second most populous country. Its socio-economic circumstances are undergoing a rapid epidemiological transition from a state of undernutrition due to poverty to obesity associated with affluence. It is now the third obese country in the world with 30 million people being obese. The obesity statistics in urban population accounts for about $73 \%$. Central obesity is a major risk factor for many diseases in modern world and it occurs when fat around the abdomen is excessive and it is likely to have negative impact on our health. A study conducted in urban New Delhi revealed the overall prevalence of generalized obesity as 50.1 per cent, while that of abdominal obesity was 68.9 per cent. The accumulation of visceral adipose tissue has been found as a major causative factor for a cluster of diabetogenic and atherogenic abnormalities described as the metabolic syndrome in modern world. Abdominal adipocytes are stuffed with excess triglycerides and pour free fatty acids into the liver, pancreas, heart, and

*Corresponding Author:

\section{Aparna Anand}

PG Scholar,

Department of Swasthavritta,

Amrita School of Ayurveda, Kerala, India

Email id: apar.000@gmail.com other organs and results in most severe complications in central obesity.

The importance of abdominal obesity in association with the development of

- Insulin resistance and hyperinsulinemia

- Hypertriglyceridemia

- Reduced plasma High density lipoprotein (HDL) and increased concentration of Low-Density Lipoprotein (LDL)

- Cardiovascular Disease

- Hypertension

- Cancers (colon, postmenopausal breast, endometrial, kidney, oesophageal, liver, and pancreatic cancer as well as non-Hodgkin's lymphoma and myeloma)

- Sleep apnoea etc. has now been well recognized, beyond the contribution of overall obesity.

Sthoulya is the nearest clinical entity for obesity in Ayurveda. In Ayurveda Athistula purusha is included under Ashtanindita purusha. Almost all Acharya's has described the disease, its lakshanas, pathogenesis and treatment. Mamsa and medas play a significant role in its Samprapti as it is a Santarpanotha vikara. The treatment modality recommended for Sthoulya is Langhana, Apatarpana, Rookshana. Udvarttana is a procedure which gives rookshana with kapha medo shamana. Moreover, it provides firmness to body, smoothness to skin and increases the complexion of the 
skin. The drugs having the qualities of ruksha, laghu, khara, teekshna, ushna, sthira, apichila, katina etc. are used for the procedure of Udvarttana which also facilitates easy liquefaction of kapha and medas. It is a well-established treatment for Sthoulya.

Naturopathy is a system of man- building in harmony with the constructive principles in Nature on physical, mental, moral and spiritual planes of being. It has great health promotive, disease preventive and curative as well as restorative potential. Water is without doubt the most ancient of all remedial agents for disease. Exposure of cold increases metabolic reaction and is effectively used in obesity. But the exact effect of abdominal cold pack in central obesity is not yet studied. Here the study was made to evaluate the combined effect of cost effective and easily adoptable remedies i.e. Udvarttana and Abdominal pack together to manage the central obesity.

\section{Aims and Objectives}

To assess the combined effect of Udvarttana and Abdominal pack in central obesity

To assess the effect of sthaanika Udvarttana with Triphala churna in central obesity.

To assess the effect of diet restriction in reducing central obesity.

\section{Materials and Methods \\ Null Hypothesis}

Combination of $U d v a r t t a n a$ with Abdominal pack has no add on effect in the management of Central obesity.

\section{Alternate Hypothesis}

Combination of Udvarttana with Abdominal pack has add on effect in the management of Central obesity.

\section{Materials}

- Triphala churna

- Treatment room provided with Dhara pathi (wooden droni)

- Vessel for keeping triphala choorna

- Abdominal wet pack- A cold wet cotton cloth (27 degree Celsius) of about 12 inches' width and 3 metres length was wrapped around the waist covering abdomen and pelvic region. This cotton pack was covered with woollen cloth of same width and length.

Method of Study: Clinical study

Source of Data: - Cases of central obesity from outpatient and in-patient department of Amrita School of Ayurveda, Kollam.

\section{Study Design: -}

The clinical study comprised of 3 groups - Each group with 20 patients.

Group 1: 20 patients were given Udvarttana with Triphala Churna along with diet restriction. (14 days)

Group 2: 20 patients were given Udvarttana with Triphala Churna and Abdominal pack. Patients were given diet restriction also. (14 days)

Group 3: 20 patients were given diet restriction only. (14 days)
Procedure

Localized Udvarttana was done with Triphala churna. Starting from the left side, horizontal movements were done lifting the fat / muscle tissue from left to right to left (at least 4-6 times). Then placing left hand over the right on the umbilicus, glide both the hands gently in clockwise direction making small circles. Gradually circles were made bigger covering the entire abdomen and then reduced the circle size coming to the centre of the abdomen. Time period 20 minutes.

For abdominal Pack- A cold wet cotton cloth (27 degree Celsius) of about 12 inches' width and 3 meters length was wrapped around the waist covering abdomen and pelvic region. This cotton pack was covered with woollen cloth of same width and length. Time-30 minutes.

\section{Inclusion Criteria}

1. Waist Circumference $>40$ inches $(102 \mathrm{~cm})$ in males and $>35$ inches $(88 \mathrm{~cm})$ in females.

2. Waist hip ratio $>0.9$ for men and $>0.85$ for women.

3. Age:25-50 yrs.

\section{Exclusion Criteria}

1. Ascites

2. Intestinal bloating

3. Age group below 25 and above 50 years

4. Patients contraindicated for Udvarttana and Hydrotherapy

5. Patients with Cushing's syndrome, taking cortisol drugs.

6. Pregnant woman

7. Patient who is addicted to alcohol or smoking. Assessments were conducted before the treatment, on 7 th day of treatment, on 14th day of treatment, after the follow up period of one week. The data were collected by interrogation and physical examination. The findings were recorded in the specific case proforma and the efficacy was compared by statistical analysis.

\section{Assessment Criteria}

1. Waist circumference

2. Hip circumference

3. Waste/Hip ratio: By dividing waste circumference with hip circumference.

4. B.M.I =Weight in $\mathrm{kg} /$ Height in metre square

5. Abdominal skinfold fat measurement

\section{Results and Discussion}

In the study total 63 patients were registered, of which 60 patients completed (20 patients each in 3 groups) the treatment. Statistical Analysis was done using SPSS VER. 20. Completed 60 patients with 20 each in 3 groups (excluding 2 drop outs) were taken for Statistical Analysis and analysis was done on Objective Parameters, to test the equality of variance. In Objective Parameters, ONE-WAY ANALYSIS OF VARIANCE (ANOVA) with POST HOC TUKEY HSD is used to find the Significance between the groups. 
Table No: 1: ANOVA of Waist Circumference

\begin{tabular}{|c|c|c|c|c|c|c|c|}
\hline & & Mean & & Sum of Squares & df & $\mathrm{F}$ & Sig. \\
\hline \multirow{3}{*}{ Waist Circumference-BT } & G1 & $97.40 \mathrm{~cm}$ & Between Groups & 308.23 & 2 & \multirow{3}{*}{3.56} & \multirow{3}{*}{0.04} \\
\hline & $\mathrm{G} 2$ & $100.05 \mathrm{~cm}$ & Within Groups & 2462.75 & 57 & & \\
\hline & G3 & $94.50 \mathrm{~cm}$ & Total & 2770.98 & 59 & & \\
\hline \multirow{3}{*}{$\begin{array}{l}\text { Waist Circumference-7th } \\
\text { DAY }\end{array}$} & G1 & $97.10 \mathrm{~cm}$ & Between Groups & 158.63 & 2 & \multirow{3}{*}{1.83} & \multirow{3}{*}{0.17} \\
\hline & $\mathrm{G} 2$ & $98.35 \mathrm{~cm}$ & Within Groups & 2461.30 & 57 & & \\
\hline & G3 & $94.45 \mathrm{~cm}$ & Total & 2619.93 & 59 & & \\
\hline \multirow{3}{*}{ Waist Circumference-AT } & G1 & $95.55 \mathrm{~cm}$ & Between Groups & 54.10 & 2 & \multirow{3}{*}{0.60} & \multirow{3}{*}{0.55} \\
\hline & G2 & $96.40 \mathrm{~cm}$ & Within Groups & 2545.55 & 57 & & \\
\hline & G3 & $94.10 \mathrm{~cm}$ & Total & 2599.65 & 59 & & \\
\hline \multirow{3}{*}{ Waist Circumference-FU } & G1 & $95.55 \mathrm{~cm}$ & Between Groups & 52.03 & 2 & \multirow{3}{*}{0.58} & \multirow{3}{*}{0.56} \\
\hline & G2 & $96.35 \mathrm{~cm}$ & Within Groups & 2551.30 & 57 & & \\
\hline & G3 & $94.10 \mathrm{~cm}$ & Total & 2603.33 & 59 & & \\
\hline
\end{tabular}

\section{Table No: 2: ANOVA of Hip Circumference}

\begin{tabular}{|c|c|c|c|c|c|c|c|}
\hline & & Mean & & Sum of Squares & $\mathrm{df}$ & $\mathrm{F}$ & Sig. \\
\hline \multirow{3}{*}{ Hip Circumference-BT } & G1 & $106.65 \mathrm{~cm}$ & Between Groups & 114.63 & 2 & \multirow{3}{*}{1.39} & \multirow{3}{*}{0.25} \\
\hline & G2 & $107.90 \mathrm{~cm}$ & Within Groups & 2345.30 & 57 & & \\
\hline & G3 & $104.55 \mathrm{~cm}$ & Total & 2459.93 & 59 & & \\
\hline \multirow{3}{*}{$\begin{array}{l}\text { Hip Circumference-7th } \\
\text { DAY }\end{array}$} & G1 & $106.60 \mathrm{~cm}$ & Between Groups & 81.70 & 2 & \multirow{3}{*}{0.99} & \multirow{3}{*}{0.37} \\
\hline & G2 & $107.30 \mathrm{~cm}$ & Within Groups & 2357.95 & 57 & & \\
\hline & G3 & $104.55 \mathrm{~cm}$ & Total & 2439.65 & 59 & & \\
\hline \multirow{3}{*}{ Hip Circumference-AT } & G1 & $106.15 \mathrm{~cm}$ & Between Groups & 28.63 & 2 & \multirow{3}{*}{0.34} & \multirow{3}{*}{0.71} \\
\hline & G2 & $105.65 \mathrm{~cm}$ & Within Groups & 2398.10 & 57 & & \\
\hline & G3 & $104.50 \mathrm{~cm}$ & Total & 2426.73 & 59 & & \\
\hline \multirow{3}{*}{ Hip Circumference-FU } & G1 & $106.15 \mathrm{~cm}$ & Between Groups & 27.43 & 2 & \multirow{3}{*}{0.32} & \multirow{3}{*}{0.72} \\
\hline & G2 & $105.45 \mathrm{~cm}$ & Within Groups & 2414.50 & 57 & & \\
\hline & G3 & $104.50 \mathrm{~cm}$ & Total & 2441.93 & 59 & & \\
\hline
\end{tabular}

\begin{tabular}{|c|c|c|c|c|c|c|c|}
\hline \multicolumn{8}{|c|}{ Table No: 3: ANOVA of Waist-Hip Ratio } \\
\hline & & Mean & & Sum of Squares & $\mathrm{df}$ & $F$ & Sig. \\
\hline \multirow{3}{*}{ Waist-Hip Ratio-BT } & G1 & 0.90 & Between Groups & 0.01 & 2 & \multirow[t]{3}{*}{2.79} & \multirow[t]{3}{*}{0.07} \\
\hline & $\mathrm{G} 2$ & 0.92 & Within Groups & 0.06 & 57 & & \\
\hline & G3 & 0.90 & Total & 0.06 & 59 & & \\
\hline \multirow{3}{*}{ Waist-Hip Ratio-7th DAY } & G1 & 0.90 & Between Groups & 0.00 & 2 & \multirow[t]{3}{*}{0.90} & \multirow{3}{*}{0.41} \\
\hline & $\mathrm{G} 2$ & 0.91 & Within Groups & 0.05 & 57 & & \\
\hline & $\mathrm{G} 3$ & 0.90 & Total & 0.05 & 59 & & \\
\hline \multirow{3}{*}{ Waist-Hip Ratio-AT } & G1 & 0.89 & Between Groups & 0.01 & 2 & \multirow[t]{3}{*}{1.11} & \multirow[t]{3}{*}{0.33} \\
\hline & $\mathrm{G} 2$ & 0.91 & Within Groups & 0.06 & 57 & & \\
\hline & G3 & 0.89 & Total & 0.06 & 59 & & \\
\hline \multirow{3}{*}{ Waist-Hip Ratio-FU } & G1 & 0.89 & Between Groups & 0.00 & 2 & \multirow{3}{*}{1.25} & \multirow{3}{*}{0.29} \\
\hline & $\mathrm{G} 2$ & 0.91 & Within Groups & 0.01 & 57 & & \\
\hline & G3 & 0.89 & Total & 0.06 & 59 & & \\
\hline
\end{tabular}

Body Mass Index (B.M.I):

Below table 4 shows the output of ANOVA analysis, and whether there is any statistically significant difference between the group means. We can infer that the significance value is 0.005 in BT and $7^{\text {th }}$ Day, 0.006 in AT and FU which is below 0.05 and therefore, there is a statistically significant difference in the mean value of BMI. But from this it's not able to tell which of the specific groups differed. To find this out the Multiple Comparisons table is used which contains the results of the Tukey HSD post hoc test. 
Table No: 4: ANOVA of BMI

\begin{tabular}{|c|c|c|c|c|c|c|c|}
\hline & & Mean & & Sum of Squares & $\mathrm{df}$ & $\mathrm{F}$ & Sig. \\
\hline \multirow{3}{*}{ BMI-BT } & G1 & 26.92 & Between Groups & 184.32 & 2 & \multirow[t]{3}{*}{5.79} & \multirow[t]{3}{*}{0.01} \\
\hline & $\mathrm{G} 2$ & 30.66 & Within Groups & 906.56 & 57 & & \\
\hline & $\overline{\mathrm{G} 3}$ & 26.97 & Total & 1090.88 & 59 & & \\
\hline \multirow{3}{*}{ BMI-7th DAY } & G1 & 26.92 & Between Groups & 184.02 & 2 & \multirow[t]{3}{*}{5.79} & \multirow[t]{3}{*}{0.01} \\
\hline & $\mathrm{G} 2$ & 30.66 & Within Groups & 905.71 & 57 & & \\
\hline & G3 & 26.97 & Total & 1089.73 & 59 & & \\
\hline \multirow{3}{*}{ BMI-AT } & G1 & 26.90 & Between Groups & 175.81 & 2 & \multirow[t]{3}{*}{5.53} & \multirow[t]{3}{*}{0.01} \\
\hline & $\mathrm{G} 2$ & 30.57 & Within Groups & 905.72 & 57 & & \\
\hline & G3 & 26.97 & Total & 1081.54 & 59 & & \\
\hline \multirow{3}{*}{ BMI-FU } & G1 & 26.90 & Between Groups & 175.81 & 2 & \multirow{3}{*}{5.53} & \multirow{3}{*}{0.01} \\
\hline & $\mathrm{G} 2$ & 30.57 & Within Groups & 905.73 & 57 & & \\
\hline & G3 & 26.97 & Total & 1081.54 & 59 & & \\
\hline
\end{tabular}

Below given is the Multiple Comparisons table which contains the results of the Tukey HSD post hoc test. (Table no:5)

From the Tukey HSD table, we can infer:

- On the $7^{\text {th }}$ day while comparing the Group2 with 1 and 3 - the mean difference is 3.743(G2 with G1) with PValue $0.012(<0.05)$ and mean difference is 3.68 (G2 with G3) with P-Value 0.013.

- On AT while comparing the Group2 with 1 and 3 - the mean difference is 3.66(G2 with G1) with P-Value $0.014(<0.05)$ and mean difference is 3.59 (G2 with G3) with P-Value 0.016 .

- On FU while comparing the Group2 with 1 and 3 - the mean difference is 3.66(G2 with G1) with P-Value $0.014(<0.05)$ and mean difference is 3.59 (G2 with G3) with P-Value 0.016.

- This indicates that Group 2 is more statistically significant than Group 1 and Group 3 on the BMI ratio.

\begin{tabular}{|c|c|c|c|c|c|}
\hline \multicolumn{6}{|c|}{ Table No 5: Multiple Comparisons: Tukey HSD } \\
\hline Dependent Variable & (I) GROUP & (J) GROUP & Mean Difference (I-J) & Std. Error & Significance \\
\hline \multirow{6}{*}{ BMI-BT } & \multirow{2}{*}{ GROUP-1 } & GROUP-2 & $-3.75^{*}$ & 1.26 & 0.01 \\
\hline & & GROUP-3 & -0.05 & 1.26 & 0.99 \\
\hline & \multirow{2}{*}{ GROUP-2 } & GROUP-1 & $3.74^{*}$ & 1.26 & 0.01 \\
\hline & & GROUP-3 & $3.69^{*}$ & 1.26 & 0.01 \\
\hline & \multirow{2}{*}{ GROUP-3 } & GROUP-1 & 0.05 & 1.26 & 0.99 \\
\hline & & GROUP-2 & $-3.68^{*}$ & 1.26 & 0.01 \\
\hline \multirow{6}{*}{ BMI-7th DAY } & \multirow{2}{*}{ GROUP-1 } & GROUP-2 & $-3.74^{*}$ & 1.26 & 0.01 \\
\hline & & GROUP-3 & -0.05 & 1.26 & 0.99 \\
\hline & \multirow{2}{*}{ GROUP-2 } & GROUP-1 & $3.74^{*}$ & 1.26 & 0.01 \\
\hline & & GROUP-3 & $3.68^{*}$ & 1.26 & 0.01 \\
\hline & \multirow{2}{*}{ GROUP-3 } & GROUP-1 & 0.05 & 1.26 & 0.99 \\
\hline & & GROUP-2 & $-3.68^{*}$ & 1.2605399 & 0.01 \\
\hline \multirow{6}{*}{ BMI-AT } & \multirow{2}{*}{ GROUP-1 } & GROUP-2 & $-3.66^{*}$ & 1.2605545 & 0.01 \\
\hline & & GROUP-3 & -0.07 & 1.2605545 & 0.99 \\
\hline & \multirow{2}{*}{ GROUP-2 } & GROUP-1 & $3.66^{*}$ & 1.2605545 & 0.01 \\
\hline & & GROUP-3 & $3.59^{*}$ & 1.2605545 & 0.01 \\
\hline & \multirow{2}{*}{ GROUP-3 } & GROUP-1 & 0.07 & 1.2605545 & 0.99 \\
\hline & & GROUP-2 & $-3.59^{*}$ & 1.2605545 & 0.01 \\
\hline \multirow{6}{*}{ BMI-FU } & \multirow{2}{*}{ GROUP-1 } & GROUP-2 & $-3.66^{*}$ & 1.2605545 & 0.01 \\
\hline & & GROUP-3 & -0.07 & 1.2605545 & 0.99 \\
\hline & \multirow{2}{*}{ GROUP-2 } & GROUP-1 & $3.66^{*}$ & 1.2605545 & 0.01 \\
\hline & & GROUP-3 & $3.59^{*}$ & 1.2605545 & 0.01 \\
\hline & \multirow{2}{*}{ GROUP-3 } & GROUP-1 & 0.07 & 1.26 & 0.99 \\
\hline & & GROUP-2 & $-3.59^{*}$ & 1.26 & 0.01 \\
\hline
\end{tabular}


Aparna Anand et.al., A Study to Evaluate the Effect of Udvarttana with Abdominal Pack in Central Obesity

\begin{tabular}{|c|c|c|c|c|c|c|c|}
\hline \multicolumn{8}{|c|}{ Table No 6: ANOVA of Abdominal Skinfold Fat Measurement } \\
\hline & & Means & & Sum of Squares & $\overline{\mathrm{Df}}$ & $\mathrm{F}$ & Significance \\
\hline \multirow{3}{*}{$\begin{array}{c}\text { Abdominal Skin Fold } \\
\text { Fat-BT }\end{array}$} & G1 & $31.95 \mathrm{~cm}$ & Between Groups & 3.62 & 2 & \multirow[t]{3}{*}{0.15} & \multirow{3}{*}{0.85} \\
\hline & $\overline{\mathrm{G} 2}$ & $32.49 \mathrm{~cm}$ & Within Groups & 675.87 & 57 & & \\
\hline & G3 & $32.45 \mathrm{~cm}$ & Total & 679.49 & 59 & & \\
\hline \multirow{3}{*}{$\begin{array}{l}\text { Abdominal Skin Fold } \\
\text { Fat-7TH DAY }\end{array}$} & G1 & $31.95 \mathrm{~cm}$ & Between Groups & 3.62 & 2 & \multirow[t]{3}{*}{0.15} & \multirow[t]{3}{*}{0.85} \\
\hline & G2 & $32.49 \mathrm{~cm}$ & Within Groups & 675.87 & 57 & & \\
\hline & G3 & $32.45 \mathrm{~cm}$ & Total & 679.49 & 59 & & \\
\hline \multirow{3}{*}{$\begin{array}{c}\text { Abdominal Skin Fold } \\
\text { Fat-AT }\end{array}$} & G1 & $31.77 \mathrm{~cm}$ & Between Groups & 5.73 & 2 & \multirow{3}{*}{0.23} & \multirow{3}{*}{0.78} \\
\hline & $\mathrm{G} 2$ & $31.81 \mathrm{~cm}$ & Within Groups & 685.59 & 57 & & \\
\hline & G3 & $32.45 \mathrm{~cm}$ & Total & 691.32 & 59 & & \\
\hline \multirow{3}{*}{$\begin{array}{l}\text { Abdominal Skin Fold } \\
\text { Fat-FU }\end{array}$} & G1 & $31.77 \mathrm{~cm}$ & Between Groups & 6.21 & 2 & \multirow{3}{*}{0.25} & \multirow{3}{*}{0.77} \\
\hline & $\mathrm{G} 2$ & $31.76 \mathrm{~cm}$ & Within Groups & 686.55 & 57 & & \\
\hline & G3 & $32.45 \mathrm{~cm}$ & Total & 692.76 & 59 & & \\
\hline
\end{tabular}

Here considering the assessment criteria's waist circumference, hip circumference, waist-hip ratio, abdominal skinfold fat measurement we can infer that while comparing the means it was found that the mean got decreased in Group 2 more compared to mean of other 2 groups; from which it is clear that there is significant change in mean of Group 2 while comparing the other group means.

\section{Overall assessment}

Considering all the assessment criteria's i.e. Waist circumference, Hip circumference, Waist-Hip ratio, B.M.I, and Abdominal skinfold fat measurement here we can see that the effect in group 2 is higher than group 1 and group 3. Group 1-Patients with Udvarttana and diet restrictions. Group 2-Patients with Udvarttana, Abdominal Pack and Diet restrictions, Group 3-Patients with Diet restrictions only.

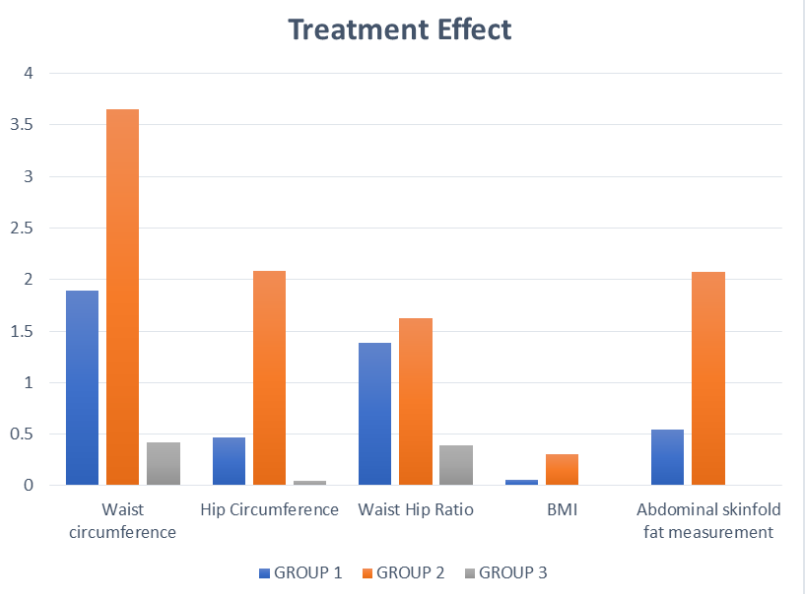

FIGURE 1: Graph showing percentage of decrease in assessment criteria's of all groups.

\section{Discussion}

Obesity, especially visceral obesity, is a common symptom found in both obese and non-obese individuals. The regional distribution of body fat is now recognized as a very important component of the obesity-related health hazards. The objective of the present study was to test whether simple, cost effective naturopathic technique i.e. Abdominal pack in Hydrotherapy will give an additive effect along with Udvarttana in reducing central obesity. Total 63 patients were registered in 3 groups (Group 1-Patients with Udvarttana and diet restrictions, Group 2Patients with Udvarttana, Abdominal pack and diet restrictions, Group 3-Patients with diet restrictions only). Among them 21 patients were registered in Group-1, 22 patients in Group-2 and 20 patients in Group-3. Out of these 63 patients, 3 were dropped out from the treatment. Gender: Majority of subjects were female. The data implies that it was the most accessible population and population of local area has prevalence of females. Religion: In this study majority of the patients were Hindus (74.6\%). Data reflects that Hindus were dominant in and around in local population. Socio-economic Status- $82.5 \%$ people were from middle class. This may be correlated with survey of Nutrition Foundation of India that middle class people are more prone to obesity. The changes in dietary practices, physical activity levels and lifestyles associated with rising affluence induced by developmental transition mentioned above contribute to the increasing prevalence of overweight/obesity. Dietary Habit: Most of the patients were having mixed diet. They were having both vegetarian and non-vegetarian food. Excess of non-vegetarian diet may be a factor for developing central obesity. The data may be correlated with studies that persons with nonvegetarian diet is 3 times more susceptible than vegetarian people. Marital status: Most of the patients were married. The reason may be that age group of inclusion criteria was above 25 years. Occupation: Data reveals that most of the patients were having 
sedentary life style. The energy intake and energy expenditure showed marked difference as the occupation was sedentary. The excess calories will be stored as fat. This may be a major contributing factor for central obesity. $25 \%$ of patients were having generalised obesity and $75 \%$ were not obese but having central obesity. This shows that persons with normal B.M.I also were prone to central obesity irrespective of generalized obesity. Regarding exercise pattern of the sample majority portion did not do any form of exercise which is a major factor contributing to fat accumulation especially in the abdominal area. Avyayama (lack of exercise) is a cause for sthoulya as told by most of the Acharyas.

When the clinical features were analyzed on Ayurvedic basics, it revealed the lakshanas of kapha dosha vikruthi. Kapha along with medo dushti is noted in most of the patients. The assessment was done before treatment, at $7^{\text {th }}$ day of treatment, after the treatment of two weeks and after the follow up period of one weeks. Group 3 was taken as control group to verify whether dietary restrictions could make any remarkable changes in parameters of visceral obesity i.e. Waist circumference, Hip circumference, Waist-Hip ratio etc.

\section{Probable Mode of Action}

Due to ruksha, ushna guna, the drugs for Udvarttana absorbs kapha and helps in reducing the excess meda and kleda. Due to sukshma guna it reaches to cellular level to digest the ama and corrects the Agni Maandya which causes sthoulya. Due to friction to all parts of the body, the ushma (heat) gets generated, this deplete the increased meda and make kapha chalatvamana. Thus, amapachana and kapha nirharana takes place.

Exposure of cold increases metabolic reaction as secondary effect and is effectively used in obesity. When a cold application is made to the body in any form, whether internally or externally, the first effect is lessening of the activities of the living structures with which the cold medium comes in immediate contact, which is termed action. Sooner or later, however, the parts return to their normal condition. This increased physiological activity is termed as reaction. Cold pack draw the blood into the surface and relax the minute blood vessels in the skin, the morbid materials in the body are eliminated through the pores of skin and absorbed by the abdominal wet packs. Cold is primarily a depressant or sedative in its effects, lowering the temperature and lessening vital activity. The secondary affect being excitant. This result from the reaction of body against the depressing influence of cold, hence the practical result of cold application for a short duration is excitatory. Abdominal pack seems to be effective in central obesity as it increases vital reaction in a localised area. The results reveal that there was reduction in all the assessment criteria's in all the three groups. But when the group means were compared Group 2 showed considerable reduction in assessment criteria's which indicates that Udvarttana along with Abdominal pack provides a simple and cost-effective way to reduce central obesity. Udvarttana along with Abdominal pack has an add on effect in reducing central obesity.

\section{Conclusion}

The preponderance of fat in the abdominal area, i.e. visceral obesity is a better predictor of both cardiovascular disease and type 2 diabetes than generalized obesity. Sedentary, affluent lifestyle and intake of high calorie diet is a major cause of increasing central obesity in present era. An effective, simple, cost effective remedy for this is the need of time.

In the present study, the observation with regards to the occupation reveals that most of the subjects were having sedentary lifestyle. This can be considered as a major cause of disease. Considering the various parameters taken for assessment viz. Waist circumference, Hip circumference, Waist-Hip ratio etc. were found to be reduced in all the 3 groups. But comparing the other two groups, Group 2 showed much difference in mean which implies that the combined treatment group i.e. Udvarttana along with Abdominal pack and diet restrictions got better result clinically. But statistically significant result was not obtained.

\section{Limits}

- Sample size is very small to draw a generalized conclusion.

- Study period was very limited.

- Longer follow up were not done.

\section{Recommendations}

Further study with a large sample size in each group is recommended.

I would like to emphasize that this truly encouraging, effective study was relatively inexpensive and hence forth, strongly recommended the same for all the affected patients, especially those belonging to the lower economic strata.

These both techniques are easily adoptable as Dinacharya procedures and can be done easily by oneself.

Udvarttana, Abdominal pack along with exercise will provide better results as the role of exercise in reducing central obesity is already proven.

\section{References}

1. Mohan V, Deepa R, Obesity \&Abdominal obesity in Asian Indians, Indian J Med Res.2006;123:593-6. [PubMed]

2. Bhardwaj S, Misra A, Misra R, Goel K, Bhatt SP, Rastogi KV, et al, High prevalence of abdominal, intra-abdominal and subcutaneous adiposity and clustering of risk factors among urban Asian Indians in North India. PLoS One. 2011;6(9): e24362.

3. Jean Pierre Despres, Is visceral obesity the cause of metabolic syndrome? Journal Annals of Medicine, 
vol 38,2006, Issue 1, Pages 52-63, published online on 8 July 2009.

4. Vaidya Yadavji Trikamji edited Charaka Samhita by Agnivesa revised by Charaka and Dridhabala with Ayurveda -Dipika commentary of Chakrapani Datta published by

5. Choukhambha Samskrita Samsthana, Varanasi, 2006, sutrasthana 21/10, page 117 .

6. Pandit Bhisagacharya Harishastri paradkar Vaidya edited Ashtanga Hridayam composed by Vagbhata with the commentaries 'Sarvangasundara' of Arunadatta and 'Ayurvedarasayana' of Hemadri, published by chaukhambha Sanskrit sansthana, Varanasi, reprint 2012sutrasthana 2/15.

7. Acharya Vaidya Yadavji Trikamji Agnivesha krita, Charaka-Drudabala pratisamskrita, Charaka Samhita with Chakrapanidatta virachita Ayurveda Deepika vyakhya, published by Chaukhamba samskrita Samsthana, Varanasi, 4th edition 2005, Sutrasthana 22/14, page 120 .
8. Henry Lindlahr M.D, PHILOSOPHY AND PRACTICE OF NATURE CURE, published by sat sahitya sahayogi sangh, Gandhi Darshan, Hyderabad, India, First Edition, Reprinted 1995, Volume 1, Chapter 3, page-22

9. Kellogg JH, Rational Hydrotherapy, National institute of Naturopathy, Dept. Of AYUSH, Ministry of Health and Family welfare, Govt.of India, Pune, second edition, 2005.

10. Manjusha Chandrakant Potdar, Arti Rajendra Firke, Effect of Triphala udvartan in obesity, World Journal of Pharmaceutical Research, Volume 5, Issue 4, page 2060-2067.

11. Henry Lindlahr M.D, PRACTICE OF NATURAL THERAPEUTICS, Volume 2, Part 2, Page 52.

12. Kellogg JH, Rational Hydrotherapy, National institute of Naturopathy, Dept. Of AYUSH, Ministry of Health and Family welfare, Govt.of India, Pune, second edition,2005, page 131. 